\title{
People Who Once Had 40 Cattle Are Left Only with Fences: Coping with Persistent Drought in Awash, Ethiopia
}

\author{
Laura Camfield $^{1}$ (D) Jen Leavy ${ }^{1} \cdot$ Senait Endale $^{2} \cdot$ Tilahun Tefera $^{3}$
}

Published online: 14 November 2019

(c) The Author(s) 2019

\begin{abstract}
How to support those responding to environmental change in resource-constrained environments is central to literature on climate change adaption. Our research explores a gap in this literature relating to the negotiation of intra-household relations and resource access across different types of household in contexts of social and environmental transition. Using the example of the semi-arid Awash region in North-Eastern Ethiopia, which has experienced drought and alien plant invasion over the past decade, we explore how men and women use changes in household structures and relationships to adapt more effectively. We draw evidence from life histories with 35 pastoralists across three rural, peri-urban and urban communities. Using Dorward et al.'s taxonomy, we find Afar people are not only 'stepping up', but also 'stepping out': shifting from pastoralism into agriculture and salaried employment. As this often involves splitting households across multiple locations, we look at how these reconfigured households support pastoralists' wellbeing.
\end{abstract}

Keywords Livelihoods · Life histories · Pastoralism · Drought · Adaptation · Ethiopia

Laura Camfield

1.camfield@uea.ac.uk

Jen Leavy

j.leavy@uea.ac.uk

Senait Endale

senaiten@ymail.com

Tilahun Tefera

tilahun_tefera@yahoo.com

1 University of East Anglia, Norwich Research Park, Norwich, Norfolk NR4 7TJ, UK

2 Addis Ababa University, Addis Ababa, Ethiopia

3 Haramaya University, Dire Dawa, Ethiopia 


\section{Résumé}

Comment soutenir ceux qui font face aux changements environnementaux dans des contextes à ressources limitées ? Cette question est au cœur de la littérature sur l'adaptation au changement climatique. Notre étude s'intéresse à un angle mort de cette littérature : la négociation des relations au sein des ménages et l'accès aux ressources entre différents types de ménages dans des contextes de transition sociale et environnementale. En s'appuyant sur l'exemple de la région semi-aride d'Awash dans le nord-est de l'Ethiopie, qui a connu une sécheresse et une invasion de plantes exotiques au cours de la dernière décennie, nous étudions la façon dont les hommes et les femmes utilisent les changements structurels et relationnels au sein du ménage pour s'adapter plus efficacement. Nous tirons des témoignages d'histoires de vie avec 35 éleveurs de trois communautés rurales, périurbaines et urbaines. En utilisant la taxonomie de Dorward et al., nous constatons que les personnes du groupe ethnique Afar ne sont pas seulement en train de progresser, mais également en train de «sortir» de leur condition, en passant de l'élevage à l'agriculture et à l'emploi salarié. Comme cela implique souvent de scinder des ménages en plusieurs endroits, nous examinons comment ces ménages reconfigurés contribuent au bien-être des éleveurs.

\section{Introduction}

The gendered negotiation of intra-household relationships and resource access and how this varies across different household structures ${ }^{1}$ is not well understood in literature on climate change adaptation (Tschakert and Machado 2012; Djoudi et al. 2016; Bunce and Ford 2015; Aregu et al. 2016). This research, carried out in 2016 and 2017 under the Adaptation at Scale in Semi-Arid Regions (ASSAR) programme, ${ }^{2}$ explores intra-household dynamics and resource access of pastoralists, agro-pastoralists and urban dwellers. The participants come from three communities in the Afar Region of Ethiopia, located in the Awash River Basin. While a rise in female headship in Sub-Saharan Africa has been noted in recent analyses of demographic change, preliminary data from qualitative fieldwork in Awash in $2016^{3}$ indicate that households are not only changing the gender of their head but also becoming more complex in other ways. We observed polygamy, household splitting, separation and consensual unions, but equally multi-generational and multi-locational households. Household structures appear to be changing as part of adaptation to climate change, recognising that a particular household structure (for example a household with more children than adults) can be a source of risk and vulnerability in some instances and support and cooperation in others (for example in sharing herding responsibilities) (Whitehead 1998; Kabeer 2008; Sen 1987). As

\footnotetext{
${ }^{1}$ For example, where households split to enable members to migrate to urban areas or pasture.

2 The ASSAR programme was funded by DFID and IDRC from 2013 to 2018 to carry out research across four semi-arid regions: East Africa, West Africa, Southern Africa and India.

3 This comprised separate focus groups with younger and older men and women and key informant interviews to select sites for the research and finalise the research design.
} 
these dynamics might play out differently over time, these initial observations from the preliminary qualitative research prompted us to explore them further in the main research by selecting a design that combined case study analysis of different household types with retrospective life history interviews.

Control over land and water resources is critical in semi-arid environments. In contexts of scarcity resulting from climatic changes, resource access often entails trade-offs. These are gendered (Perez et al. 2015) and 'aged', as they relate to the aspirations of younger and older generations. For example, many parents aspire to education and salaried employment for their children, rather than agriculture (Chuta and Crivello 2013; Tafere 2014). Given the centrality of age, gender and location in jointly shaping household structures and relationships and, consequently, the nature of risks as well as adaptation (Rao 2019; Rao et al. 2019), our overarching research question is:

How Do Men and Women (of Different Groups, Ages and Statuses) Use Changing Household Structures and Relationships to Respond to Risks and Adapt More Effectively?

The paper uses Dorward et al.'s (2009) taxonomy of 'hanging in', 'stepping up' and 'stepping out', developed to categorise the strategies and aspirations of poor people in Mexico and Bolivia, to look at the ways in which people have responded to these challenges. Their responses include 'hanging in' through travelling longer distances to pasture or moving family members and high-value livestock to traditional rangelands, 'stepping up' through engaging in activities alongside pastoralism, including migration, and 'stepping out' through moving to urban centres and engaging in nonagricultural activities (see also Little et al. 2001). As described earlier, these strategies have involved the creative refashioning of household structures to respond to new expectations and realise aspirations. These are typically centred around education and employment, as we discuss in the final section.

\section{Methodology}

Our study of intra-household dynamics and adaptation under social transition is based on in-depth interviews with households in the Awash River Basin, conducted in October 2017. ${ }^{4}$

\footnotetext{
4 The study was approved by the University of East Anglia (UEA) research ethics committee in 2016, which follows the Economic and Social Research Council (ESRC) research ethics framework. Informed consent was secured after discussion at community and individual levels where information on the study and expectations of participants were shared. The consent was recorded by the researchers to avoid the participants, who were mostly illiterate, being asked to sign or make a mark. The participant names in the table have been anonymised, although as the study is not particularly sensitive, the community names have been retained.
} 
Table 1 Household categories

\begin{tabular}{|c|c|c|c|}
\hline \multirow[t]{2}{*}{ Category } & \multicolumn{3}{|l|}{ Location } \\
\hline & Rural (Dileyu, pastoralist) & $\begin{array}{l}\text { Peri-urban (Melka Sedi, } \\
\text { agro-pastoralist) }\end{array}$ & Urban (Sabat Kilo) \\
\hline Young & 1. Abahina and Edole & 1. Humed and Aisha & $\begin{array}{l}\text { 1. Fatuma } A \text { and Sadam } \\
\text { 2. Ibrahim and Hasena }\end{array}$ \\
\hline Polygamous & $\begin{array}{l}\text { 2. Ali } \mathrm{H} \text { and Meyro } \\
\text { 3. Fatumah } \mathrm{F} \text { and Haye }\end{array}$ & & 3. Ahmed A \\
\hline Monogamous & 4. Hassen and Sabera & 2. Abahina and Handei & $\begin{array}{l}\text { 4. Ahmed S and Medina } \\
\text { 5. Fatuma M and Dediso }\end{array}$ \\
\hline Divorced & 5. Fatuma $\mathrm{G}$ and Musa & 3. Mohammed and Hawa & $\begin{array}{l}\text { 6. Husseni } \\
\text { 7. Bidar }\end{array}$ \\
\hline Widow/widower & $\begin{array}{l}\text { 6. Gerad and Ali A } \\
\text { 7. Ahadi }\end{array}$ & & $\begin{array}{l}\text { 8. Amer } \\
\text { 9. Seid and Meryam } \\
\text { 10. Hassena }\end{array}$ \\
\hline Total household & $7(13)$ & $3(6)$ & $10(16)$ \\
\hline
\end{tabular}

Total individual interviews in parentheses

\section{Methods and Sampling}

We used an initial census survey of households in the communities to generate a deeper understanding of household structures, livelihoods and adaptation behaviours in each site. The survey was administered on paper by two enumerators who worked with the senior man and senior woman in each site (the household head - usually but not always male-answered a longer version of the questionnaire). All the questions were closed-ended and mixed-objective questions (e.g. household structure, assets and activities) with subjective questions on perceptions of environmental change and measures of satisfaction with life as a whole and different dimensions of life such as family health. The main limitations of the survey in relation to our study are that it does not cover the urban site and, due to an error in recording household IDs, it was not possible to use it to subsample the life history interviews as originally planned. As we were only able to find one Afarigna-speaking female enumerator, the quality of the data from the surveys administered to women is perceptibly lower. We then purposively sampled life history interviews to examine how households are coping with environmental and climate stresses, and the effect of these on the choices they make and the opportunities available to them. The sample comprised 35 life history interviews with households from the pastoralist village Dileyu (13 people), the agro-pastoralist and peri-urban centre Melka Sedi (6 people) and the urban neighbourhood Awash Sabat Kilo (16 people). These were conducted by the authors, working through an interpreter. While it would have been good to have looked at context and type of occupation separately, unfortunately in this case they were the same, although even urban residents thought of themselves culturally as pastoralists. Where possible, two people were interviewed in each household, typically the household 


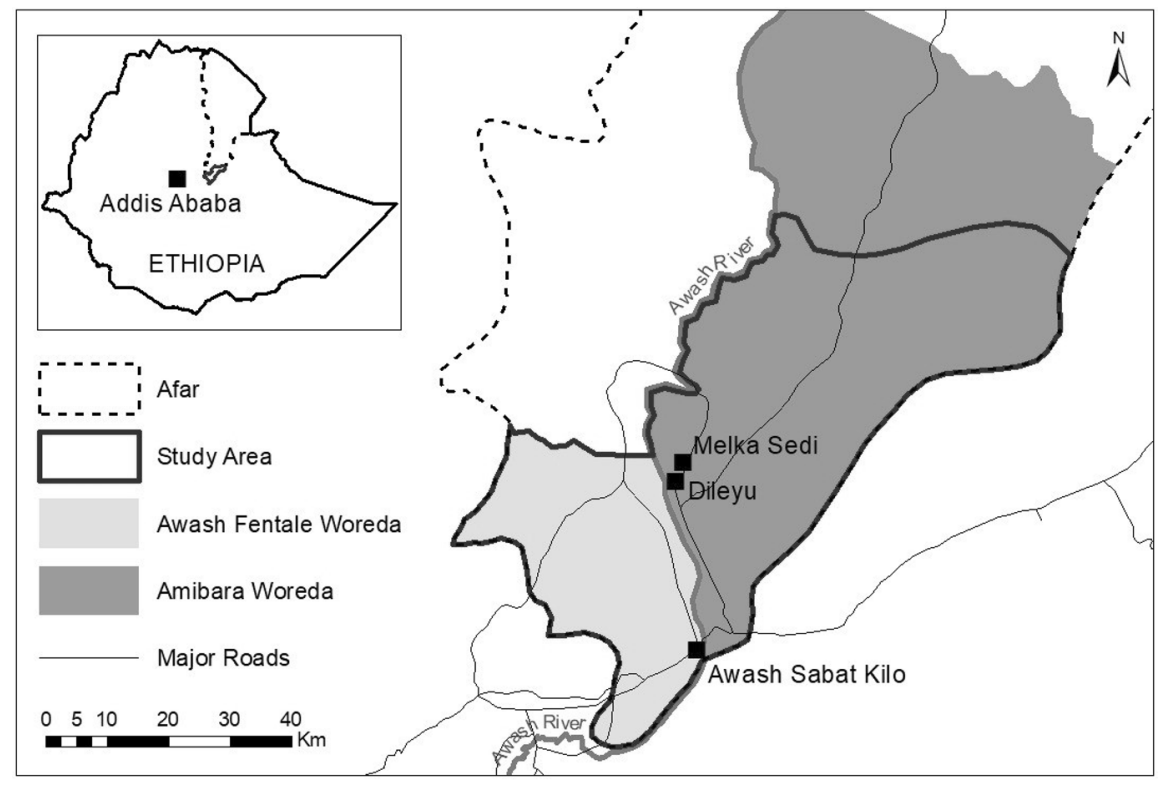

Fig. 1 Map of the study area, showing the three settlements

head and senior man or woman, depending on the gender of the head. We look specifically at monogamous, polygamous, divorced, widowed/older and young households (where the household head is aged under 30) to see how household type can mediate adaptation to climate change (Table 1).

\section{Sites}

The location of the three sites is as follows: Awash Sabat Kilo is situated on the outskirts of Awash Town, $7 \mathrm{~km}$ from the customs post on the Djibouti road. Melka Sedi is located close to the government-owned sugarcane plantation at Kesel Toli (also known as Mus Kamp) where large-scale irrigation was established in the 1960s. Diyelu is a short motor cycle ride from Kesel Toli, and some residents work there (Fig. 1).

Given that the focus of the study was pastoralists responding to environmental change, our primary focus was the largest settlement of Dileyu. However, on arriving in the site, we realised that households and livelihoods in Melka Sedi were structured differently and this was important to capture, as some households in Dileyu aspired to move to Melka Sedi as part of a longer-term migration strategy (Dileyu and Melka Sedi were treated as a single site-Kesel Toli-when they were surveyed). 


\section{Background}

To provide some context, we draw on data from a survey $(n=298)$ administered in 2016 to four communities, two of which have been included in this study. ${ }^{5}$ Our survey data suggest that people in our sites are mainly Afar, with generally low levels of education. None of the household heads had completed secondary schoolingthe highest recorded was grades $1-4$ of primary, ${ }^{6}$ and none of the female household heads had completed any education. Just $10.5 \%$ of female household members had completed the first cycle of primary school, which is the point at which they would be considered literate, versus $17.3 \%$ of men.

In terms of environmental change, the Awash Region has witnessed persistent drought, ${ }^{7}$ sudden flooding and alien plant invasion (Prosopis juliflora, a type of acacia) over the past decade. Our survey data show the environmental pressures people have been experiencing, with over $85 \%$ reporting longer dry seasons, reduced, delayed and erratic rainfall, and stronger winds over the past 10 years. The majority of respondents reported a dramatic reduction in the availability of resources such as water, rangeland and fertile soil. These required households to travel longer distances to pasture on a daily basis, which often meant that older children could not attend school alongside herding. They might also relocate entirely to different pasturelands during the dry season, or send cattle to stay with family members at their homes (if they had better access to pasture and more people to herd) or at the communal pasturelands where two or three people would manage the herds of multiple households. Where households migrated to urban areas, they would leave their livestock with other family members to be looked after. If the migration was successful, they would send back money to purchase more livestock; if it was not, they would ask their relations to sell their livestock and send them a portion of the profits. These strategies were prompted by the reduction in pastureland which caused $79 \%$ of men and $64 \%$ of women to describe climate change as having had significant effects on their livelihoods. Ahadi (pastoralist, widow) described how "before the drought 4 years ago, I had 50 camels, 50 cattle, 100 goats and 50 sheep. But now, I have no camels, 6 cattle, 30 goats and 10 sheep." Amer (urban, widower) told us how yearon-year he lost animals (he originally had 7 cattle, 30 goats and 20 sheep), with the final one dying last year: "People who once had 40 cattle are left only with fences."

Drought was reported as the major event that had happened to them in the last 10 years, and this has been particularly acute since 2015, with the arrival of water tankers in many communities. The droughts cause massive loss of livestock for the majority of rural pastoralists and agro-pastoralists, as well as those now living in town. This has nutritional impacts, as livestock are not only assets but also a source of butter and milk. Consequently the loss of livestock was said to have affected children severely—Haye (pastoralist, polygamous) said "look at those boys [lifting the

\footnotetext{
${ }^{5}$ The four communities were the agro-pastoralist communities of Melka Sedi and Yourin, and the pastoralist communities of Dileyu and Gonita Birka.

${ }^{6}$ The first cycle of primary school; the full cycle runs to grade 8 .

7 Since 2003, the Afar Region has experienced five serious droughts, of which the worst was the 2015/2016 El Niño drought, which is the one that most respondents refer to in the results section when they talk about drought.
} 
arm of a child] — when I was young we have enough milk and we are fat and strong. Look at those children, they are thin." Fatuma G (pastoralist, divorced) was one of many to compare the present unfavourably with the past: "life was so cheap [then] and we bought so many assets with small amounts of money, but now money loses its value." In the empirical section that follows, we present the data from the life history interviews in relation to the three categories of 'hanging in', 'stepping up' and 'stepping out', drawing out the differences between the types of households that were able to pursue them.

\section{Findings}

\section{'Hanging in'}

Migration in search of pasture and water are a typical activity of pastoralists (Musa, pastoralist, divorced) and take on greater importance in times of drought. ${ }^{8}$ Ali described how half of his family members migrated with livestock during this period. As a result of the drought, respondents reported travelling further to pasture on a daily and a seasonal basis and consequently spending longer periods of time away from home. Gerad (pastoralist, widower) described how the entire household needed to work together to manage the herding given the distances involved. Even young children are involved, and they do this in shifts so they can go to school as well. Ahadi (pastoralist, widow) described how "often during drought, we are moving to Manasefa, a $3 \mathrm{~h}$ walk from my village. The entire family is moving except my father [who has a job] and my half-sister... Usually, we will spent around 2 months at Arteya [5 h from the village] and 5 months at Manasefa and then we will return to our villages. Because of our seasonal migration, we will save our livestock from death [and] get better milk products." Sometimes whole families moved, as Ahadi describes, but often it was just men or occasionally older women or boys.

Migration comes with certain risks and vulnerabilities: exposure to conflict with pastoralists from different tribes due to competition over scarce resources, the need to be able to feed yourself while away and increased vulnerability to illnesses such as malaria if food provisioning was not successful (Das et al. 2018 ${ }^{9}$ ). Five of the respondents (Edole, Musa, Hawa, Hamid and Mohammed) mentioned direct experience of conflict, and it was clearly a factor in the decision-making of all the pastoralist households. Edole (pastoralist, young) described being expelled at gunpoint from the pasture land of the Argoba, a rival group of pastoralists, after he and his brothers had migrated for pasture. Musa (pastoralist, divorced) described experiencing a "clash conflict—where we fired [rifles] towards the sky to frighten them but didn't hurt them." Fortunately, the latter was resolved by elders within the community and Musa was able to stay at the pasture for 3 months.

\footnotetext{
8 See Sandford (2006) and Devereux and Scoones (2006) in relation to the Somali drought.

9 The connection between malaria and malnutrition was mentioned by respondents and supported in Das et al.'s (2018) recent review which suggests there are causal linkages in both directions.
} 
Although elders can play an important role in resolving conflict, both Dediso (urban, monogamous) and Haye (pastoralist, polygamous) described losing livestock through conflicts or raids. Despite the known dangers of migration, for example exposure to physical or sexual violence (Bank et al. 2017) and the disruption caused when children's schooling was interrupted (UNESCO 2017), the respondents considered it was far worse to be unable to migrate due to age or gender. Fatuma (pastoralist, monogamous) described how she and her husband "suffered in times of drought by staying home and suffering the consequences due to [our] age", for example, having less nutritious food. While Fatuma was talking primarily about those left behind due to age, she characterised this as a problem of proscriptive gender roles because "women will severely be affected by the problem as they have to stay home and suffer the consequences while the men look for pasture... it will be good for women to move with others and with the cattle in order to get what she needs such as milk, butter etc." Musa (pastoralist, divorced) also observed that "their life would be difficult, if they were not able to migrate to better places [as] their animals' life would be lost due to the problem of water, grass and diseases."

The drought and the growth of indigestible prosopis, which harbours wild animals ${ }^{10}$ and disease-carrying fleas, had supported the spread of livestock disease. Ahadi (pastoralist, widow) said her household had lost much of its livestock through an epidemic where "the stomach of the goats and cattle bulged out and this was then followed by diarrhoea." Not surprisingly, many households decided not to restock their livestock after losing them to drought or disease. Some moved from camels and cattle to goats, which were lower risk but less lucrative, as they were concerned about future rainfall (e.g. Ahmed A, urban, polygamous).

Other strategies to cope with drought included bringing grasses from different areas to feed the animals (Meyro, pastoralist, polygamous). However, this was not enough to prevent loss of livestock (Ali $\mathrm{H}$, pastoralist, polygamous). As the severity of the droughts was not immediately obvious, households hung on to their livestock as long as possible and often lost the opportunity to sell them at all_-"we lost them by drought... it would have been better to sell with cheap price" (Ahadi, pastoralist, widow). Others described sending cattle to family because they lived too far away from the pasture (Hawa, peri-urban, divorced) — this was a common concern for urban or peri-urban migrants-or with children enrolled in school there was no-one to herd them (Handei, agro-pastoralist, monogamous). However, support from family comes with an obligation to reciprocate. Hawa (peri-urban, divorced) said she was tired of the requests her brothers make in exchange for keeping her cattle, as they always ask her "to send them food and whatever they want", even when "there is a shortage of food at home".

People highlighted that, because drought affects everyone, it erodes the strength of their social support networks, including family. Ibrahim (young, urban) described how "before the entire Afar region was seriously stricken by drought 3 years ago, my relatives and clan brought me milk, butter and bakels [he-goats/billy goats].

\footnotetext{
10 Ali Abdul described how "the growth in prosopis during the drought has created places for wild animals to hide and they take the livestock; I can't protect them."
} 
This assistance was quite helpful to the livelihood of my family. But, the drought... makes all Afar households to same level in terms of their living standards. So, no households are capable of helping the other." Now the expectation is reversed as, because he earns a salary, "currently, my relatives and clan expect some help from me."

Clans and other traditional social networks were described as important sources of support; for example rural and urban women were involved in informal women's associations and Iddir (burial societies). Meyro (pastoralist, polygamous) said that she received support when her first husband died, which would have been in the form of small amounts of money and cooked food to help with the Lekso (mourning period). Musa (pastoralist, divorced) said that he borrowed from friends and neighbours, but Ibrahim (young, urban) observed that "drought is making all households poor and less able to help each other." Many households said that they obtained food on credit from local shopkeepers without paying any extra (e.g. Sayid, Haider). However, this could have a negative effect on businesses-Sadam (young, urban) said that he went bankrupt for this reason: "I used to have a lot of [rural Afar] customers and I gave them different food items in loan when they request me... Because of that drought they lost their livestock; hence, they were unable to pay me back [as] formerly they paid me back after they sell milk and bakels."

Households were increasingly reliant on food aid-Ahadi (pastoralist, widow) describes how "each month I received $50 \mathrm{~kg}$ wheat ${ }^{11}$ and 3 litres of oil. The government provided us with this aid through the Productive Safety Net Program (PSNP)". Pastoralists were also provided with fodder for their animals-Hawa (peri-urban, divorced) described receiving four Bonda (bundles) of grass weighing approximately $17 \mathrm{~kg}$ each on two occasions. Medina (urban, monogamous) confirmed this, although she only received grass while she was living in a rural area, ${ }^{12}$ even though many urban residents had livestock. Some respondents, e.g. Mohammed (peri-urban, young), said that "the PSNP is disorganized and the support is insufficient." There appeared to be little additional support from $\mathrm{NGOs}^{13}$ - "there is nothing special for young people, for example, job opportunities, at all" (Mohammed).

Hanging in therefore comprises a range of adaptation strategies involving migration to urban centres or to pastures with livestock, and the sale of livestock. All strategies are occurring in a context of drought, reduced pasture land due to both drought and invasive species, and related risks such as livestock disease, and involve some risk (for example conflict with other pastoralists). Respondents described the value of social networks in the context of limited government support.

\footnotetext{
11 Others received maize in similar quantities, proportionate to the number of household members.

12 This was also true of PSNP (Hassena, urban, divorced), although in some cases families in rural areas would send food to members in urban centres.

13 One respondent (Humed, urban, young) recalled receiving goats from Save the Children.
} 


\section{'Stepping up'}

While in the Afar Region of Ethiopia many households have moved from a predominantly pastoralist livelihood into agriculture (agro-pastoralism) and other forms of livelihood diversification, agriculture is still largely rain-fed and vulnerable to the risk of drought. Gerad (pastoralist, widower) described how he would like to do agriculture instead of pastoralism, but currently it is not viable- "there is no rainfall here. I would like to get water through irrigation channels like the ones the sugar plantation uses and then I could cope with the drought." A common strategy described in the case studies is to have multi-locational households and household members. This enables households to diversify income-generating activities and alleviate pressure on resources in the sending (usually rural) household. As well as the relief of not having to provide for another household member, households benefit from remittances from absent members and relatives [for example Sadam (urban, young) sends support, including Khat, to his father]. Bidar (urban, divorced) works as a registrar in the Sharia court; one of only two within our sample with a whitecollar occupation. He earns 4000 ETB per month and sends half of this to support his ex-wife and children, who live with his stepmother in a rural area.

Remittances are an important part of diversified livelihoods; For example, Musa (pastoralist, divorced) describes how his seven-person household depends on his father's salary as a guard in the sugarcane plantation (1000 ETB per month), about 700 ETB per month from livestock sales and remittances from sisters in Djibouti and Awash, totalling 17,000 ETB per annum. ${ }^{14}$ Nearly a quarter of the sample had family members in Djibouti, which could bring considerable benefits. Edole (pastoralist, young) described how "my wife's sister is living in Djibouti and she sent for us about 4000 ETB every 2 months. Besides, she also sent for us foodstuffs such as, sugar, macaroni, pasta, oil."

Not all urban residents can remit, however, due to the costs of living in town. Ahmed A (urban, polygamous) lives in town with his second wife, while his first wife is still in the rural area. When asked why he relocated with one household, he said he felt it would be better to be in Awash Town, not only for his children's schooling but also to be close to his extended family, some of whom had already migrated for employment. He now works as a guard in a government office, having been told by relatives that this job was available. He is building a house in town using money earned on an 8-month contract working as a foreman for the Turkish company carrying out railway construction; however, he says: "I need up to 10,000 birr to complete [the house]. I need to get another job [alongside the guard job] first." Even with a salaried job he says that "things are expensive so my salary is not enough to cover my children's needs [for] books, pencils, clothes." He chose not to restock his livestock as "because of drought there is no grass. It makes no sense [to restock]." Similarly, Hassena (urban, widow), who moved to Awash on her

\footnotetext{
${ }^{14}$ See also Devereux and Scoones (2006), who identify remittances from the Somali diaspora as crucial in sustaining Somali herder life styles.
} 
own to work in a cotton factory while leaving her children with family near Awash Arba, now sells coffee on the main road into town. She notes that, with rising sugar prices, "my net earnings is not more than 20 ETB per day after deducting my cost." Rather than remitting money as she had done in the past, she relies on small, ad hoc amounts from her elder son when he sells one of the male goats she left with him. ${ }^{15}$

Migration could also increase the pressures on rural households where children are sent to their grandparents, uncles/aunts or cousins, to enable their parents' migration. This was the case for Hawa (agro-pastoralist, divorced), who took in her niece Ferha after her mother moved to Djibouti and her father to Awash Town. Taking in children can be positive, however; Gerad (pastoralist, widower) looked after his grandchildren from the age of three so they could support him in herding.

As part of livelihood diversification, households engaged in illegal activities such as selling charcoal, or taboo activities such as selling milk for five ETB per cup. ${ }^{16}$ This is not normally done by pastoralists but, according to Haye (pastoralist, polygamous), is necessary because "now there is a shortage of money to buy sugar and coffee so we have to sell milk." One respondent admitted to making and selling charcoal made of prosopis, which is illegal (Berie, pastoralist, monogamous), and there may have been others doing this.

The importance of a salary or other non-farm income, for both pastoralists and agro-pastoralists, is evident in our case studies. Many people reported working on the sugarcane plantation, either as daily labourers or as guards. Ahadi (pastoralist, widow) described how her father's job as a guard accounts for a third of their income and provides the majority of their food. Meyro (pastoralist, polygamous household) described how when her children need medical treatment, shoes and clothes, she pays for these from her sugarcane income. Despite their importance, jobs at the sugar plantation tend to be insecure and without any benefits, including in cases of injury (Meyro, pastoralist, polygamous) or pregnancy. Abahina (agro-pastoralist, monogamous) described how "when I was over 6 months' pregnant, the sugarcane plantation stopped my salary. I did not get any salary until I gave birth and returned to work." Gerard (pastoralist, widower) described how, despite working as a security guard at the plantation for 30 years, he is classed as a temporary employee so does not get any benefits and receives less than the legal minimum wage. He puts his status down to the fact that when he started the job during the Derg ${ }^{17}$ he was not a member of the ruling political party. Now there is no formal requirement to be a party member, "although it helps"; however, he feels he is too old to be given a permanent job.

\footnotetext{
15 This phenomenon has been observed in other settings, e.g. Botswana (Campbell 2010).

16 Among pastoralists in Somalia and Ethiopia, milk selling has been taboo (e.g. Guadu and Abebaw 2016), although those who transgressed were not punished. However, there is some evidence that this is changing in response to projects such as that of the International Livestock Research Institute (ILRI) which focus on improving handling practices and microbiological safety of milk and milk products to exploit the potential of this market. http://livestocklab.ifas.ufl.edu/projects/dr-kebede-amenu/.

17 The socialist regime that preceded the current one and ended in 1991.
} 
The small number of agro-pastoralists within the sample (three households, six respondents) were located in Melka Sedi, near the sugarcane plantation and irrigation channels. While these tended to be wealthier than others within the sample, this was because their wealth enabled them to manage the risks associated with agriculture, rather than that their wealth had been accumulated through agriculture. For example Berie (pastoralist, monogamous) says that he wants to move into growing cotton and vegetables on land which the kebele ${ }^{18}$ will give him, but emphasises he can only do this if he can get credit (he mentions this twice). Agro-pastoralists engaged in multiple livelihood activities alongside agriculture, many of which were more typical of urban centres (for example, motorcycle taxis). Humed (agro-pastoralist, young) is a farmer with three hectares planted with cotton. He also runs a motorcycle taxi, ${ }^{19}$ and his wife sells tea, coffee and breakfast in a rented 'hotel' (she keeps her profits- “even I didn't see her money"-but there is not enough to save). His family hold livestock for him in Dileyu, which are his "security" (he used the English word) if he has a problem or needs capital for farming. He farms on land he cleared himself and said that he "gets a couple of harvests from each planting". If he has a good harvest of cotton, he sells 80 kuntal $^{20}$ per annum; if it is poor, 70 kuntal (he earns 1100 ETB per kuntal, total 77,000-88,000 ETB per year). He has been farming cotton for 4 years, and the second year after he started, his harvest failed and he lost most of his produce due to shortage of water: "Even though I was providing chemicals, the planting will not be successful unless it gets water." Despite having irrigation, the Awash River was too low to fill the irrigation channels, which caused other farmers to lose their cotton as well. The sugarcane plantation was not affected as sugarcane does not need as much water; however, he cannot grow sugarcane as an individual because the government will not buy sugarcane from individuals and there are no private factories to process it. In addition to the uncertainty, farming requires hired labour and inputs such as the tractor to clear the prosopis, which is "too costly" at 8000 ETB. His wife currently sells tea and coffee but does not plan to continue as this is "heavy work" and her husband cannot help her. She talked about opening a shop in the future as "it's not difficult to do... shops are more profitable." However, she concluded that "if I get a good job, rather than tea, I will change, but if there aren't any good jobs, I will continue."

Households engaging in stepping up are diversifying into other activities, for example growing cotton, selling tea and coffee, working as a guard and supporting the migration of household or family members who will send remittances. While these activities can be successful, they often require substantial resources (e.g. to farm cotton or run a motor cycle taxi) and may also be dependent on an uncertain climate or precarious employment.

\footnotetext{
18 A kebele is the smallest administrative unit of Ethiopia, similar to a ward or neighbourhood.

19 His motorcycle cost 39,000 ETB from Addis (over $£ 1000$ at the current exchange rate-one Ethiopian birr to $£ 0.03$ ), and he paid for it with the profit from the farm.

20 A kuntal or quintal is equivalent to $100 \mathrm{~kg}$.
}

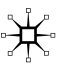




\section{'Stepping out'}

Most of the urban households were migrants, and in many cases, the move to town was in response to the impacts of drought on their livelihoods. Ahmed S (urban, monogamous) described moving first to pasture for 3 months, and then, as his herd diminished (from 35 cattle to 10), he left them with his brothers and moved to Awash to work as a taxi broker. Urban residents engaged in salaried work, where this was available, or petty trade (e.g. selling potatoes), while still retaining a foot in more rural occupations such as livestock. Ibrahim (urban, young) talked about the "pull" of the prospect of jobs in town: "I migrated from my birth place in search of jobs. I came here because I had heard that jobs were being created for young people by government." He met his wife, Hasena, in Awash, where she had migrated with her natal family due to the drought.

For urban residents, a salaried job was often part of their motivation for migration as it offered greater security than livestock. After Amer (urban, widower) lost his livestock due to drought, he moved to Awash. He secured a job as a guard for 'the telecoms', where he has worked for 15 years, after repeatedly asking the administrators if there were jobs available. Dediso (urban, monogamous) works as a guard, his wife works as a cleaner, and his daughter is a policewoman (unusually, she manages her own income and contributes 1000 ETB per month to the household). Neither he nor his wife have any schooling, suggesting that luck and persistence can be as importance as basic education in securing unskilled employment.

Others engaged in petty trade or daily labour, e.g. on the railway line or in other forms of construction, which were marginal activities. For example, Meryam (urban, widow) made shiro (ground chickpeas, peas or beans) and ground pepper to sell to supplement her income as a cleaner until she ran out of capital to buy the raw materials. Her son worked in the bus station every other day carrying luggage. This shows that urban livelihoods are not always better than rural ones. While some urban residents made enough to remit to family in rural areas, others accepted remittances from family living elsewhere. For example, Ahmed S (urban, monogamous) described receiving 2000 ETB every 3 or 4 months and about 2000 ETB on every religious holiday from his brother. 'Stepping out' was therefore not always into a bright future but could be just a way of repeating experiences of hard work and exclusion in an even less welcoming environment. In the final section, we look at whether and how these experiences of drought and precarity translate into aspirations for the future for both children and adults.

\section{Aspirations}

Aspirations for children were uniformly framed around education and urban employment, even among older pastoralists. Respondents mentioned "work in an agricultural office or the water sector or anywhere else in a government office" (Humed, agro-pastoralist, young) or in professions such as engineers or doctors: 
"I want my children to get better education [than I did]. In the future, they have to live in towns and cities. They should make their living from their educational career." Abahina (young, pastoralist).

"I want my children to be educated to a higher level, to university and college, and get good jobs with a good salary." Gerard (pastoralist, widower).

"Education is an advantage; previously we didn't have it. [My children] know - they read, they speak, they learn. If they are educated they have the chance to find jobs in government and they won't keep livestock as we do." (Haye, pastoralist, polygamous).

Some were motivated by a feeling that they had missed out on educational opportunities. Bidar (urban, divorced) said "I feel regret for not attending modern education. I did not have access to education. But, my dream has to be realized through my children." Humed (agro-pastoralist, young) and Sadam (urban, young) expressed similar sentiments. Others wanted to ensure that they received support in the future when they were too old to work (Meyro, pastoralist, polygamous; Haye, pastoralist, polygamous). Most were positive about their children's chances of success, but others were more pragmatic: "If they fail, they bring their axe and go to the fields and farm like me. There are people who finish education, but don't have a job." (Humed, agro-pastoralist, young). One example of this was Seid, the unemployed son of Meryam (urban, widow), who said in relation to his own life "I don't want to think about the future." Unfortunately, we were not able to interview many young people, so we cannot talk about whether these aspirations are realistic-given the quality of education and the size of the labour market in Ethiopia (Tafere 2014). However, two focus groups with young men and women during the preliminary fieldwork suggest that more people were living like Seid than had succeeded in becoming doctors or engineers.

Adults also held aspirations that centred on moving to urban centres- the 'stepping out' strategy described in the earlier section. Edole (pastoralist, young) works during the day in the sugarcane plantation as a labourer and at night as a guard to earn enough money to buy a bajaj (small motorised vehicle). He says "I am also dreaming to live in town." His wife, Abahina, says separately "I want to move to town if I have a better income. I dream to have shop in the town. Despite this dream, it is difficult to me to detach myself from our pastoral way of life... However, if we get someone to herd our livestock, it will be nice to live in town." Finally, Hawa (agro-pastoralist, divorced) says that the culmination of her plans to expand her livelihood activities will be to live in town in a large house. While respondents held high aspirations for their children, and to a lesser extent for themselves, there is little evidence that these can be achieved in an environment with multiple barriers to schooling and little skilled employment (Camfield 2011). 


\section{Conclusions}

It was clear from across our case studies, and in line with other research, that pastoralists and agro-pastoralists in Awash are experiencing considerable stress due to climatic changes. This is felt in a range of ways-water (both for domestic use and livelihoods) and pasture scarcity, erosion of herds, declining quality of livestock and decline in agricultural production-with direct negative impacts on wellbeing through the effects on incomes, food security and nutrition. People manage this through livelihood diversification, including migration to urban centres and spreading households across pastureland and rural and urban centres. Dorward et al.'s taxonomy of 'hanging in', 'stepping up' and 'stepping out' captures this well, although given the severity of the problems faced by pastoralists in this area, the fourth category of 'falling down and out' (Dorward, pers. comm., 2011), where people are not leaving pastoralism by choice but because they have lost all their assets, needs to be added. Government food aid plays an important role in preventing this as family and broader social networks are placed under increasing pressure. Because 'stepping up' activities tend to still rely on natural resources, it was evident from our case studies that these remain precarious and cannot be considered to be a successful adaptation to climate shocks and stresses. Even jobs in the sugarcane plantation, while an important source of income for households and a way to buffer risk, are precarious insofar as these tend to be poor-quality jobs with low salaries, no benefits or guarantees and few formal, permanent contracts.

In some cases, households split location, keeping a foot in both rural and urban livelihood activities. Despite the importance of livestock to being a pastoralist, urban interviewees with a rural livelihood activity alongside their urban job seemed to expect the rural activity, usually livestock, to come to an end eventually. This was due to the decision not to restock or breed should they lose (more) livestock to drought and other climate-related shocks, thereby eventually running herds down to zero. The reconfiguration of the household increases opportunities for female agency (for example Hassena's decision to migrate to Awash to work in a cotton factory or Hawa's to take in her niece Ferha to enable her sister to migrate independently to Djibouti). However, it also increases pressure on women to support their children, especially if they are divorced, widowed or in a polygamous household. Few employment opportunities for young people mean that women in these households may be the sole breadwinner.

One of the main contributions of the paper is the differentiated analysis, which looks at how responses are shaped not only by social markers such as age and gender but also by household structures. Following Sen, we highlight the presence of cooperation alongside conflict and show how, in situations of crisis, cooperation, particularly between kin, becomes more visible.

Despite their current circumstances, respondents continue to be optimistic about their children's future, while recalling a more prosperous past. Our research suggests that, to improve the wellbeing of people living in semi-arid areas such as the Awash River Basin, who are heavily dependent on natural resources for their livelihoods (pastoralism, agro-pastoralism, agriculture), the focus should be on supporting 
adaptation and resilience. This could include generating forms of employment that are not reliant on natural resources or affected by the vagaries of the weather and climate, for example providing opportunities for young people such as skills training that match up with the realities of the job market and take into account youth aspirations for work outside farming. As currently there are few formal jobs outside regional centres, this could include access to affordable credit and initial capital to start micro-enterprises and ongoing training and mentoring to support these, recognising that these have not always been successful (di Nunzio 2015). Finally, as pastoralist organisations have long argued, pastoralist livelihoods should be underpinned by improved basic services such as health, including maternal health, and strengthened productive and social safety net programs to help more households recover from environmental shocks and stresses.

Acknowledgements This work was carried out under the Collaborative Adaptation Research Initiative in Africa and Asia (CARIAA) with financial support from the UK Government's Department for International Development and the International Development Research Centre, Ottawa, Canada (grant no. NK). The views expressed in this work are those of the creators and do not necessarily represent those of the UK Government's Department for International Development, the International Development Research Centre, Canada or its Board of Governors.

\section{Compliance with Ethical Standards}

Conflict of Interest On behalf of all authors, the corresponding author states that there is no conflict of interest.

Open Access This article is distributed under the terms of the Creative Commons Attribution 4.0 International License (http://creativecommons.org/licenses/by/4.0/), which permits unrestricted use, distribution, and reproduction in any medium, provided you give appropriate credit to the original author(s) and the source, provide a link to the Creative Commons license, and indicate if changes were made.

\section{References}

Aregu, L., I. Darnhofer, A. Tegegne, D. Hoekstra, and M. Wurzinger. 2016. The Impact of Gender-Blindness on Social-Ecological Resilience: The Case of a Communal Pasture in the Highlands of Ethiopia. Ambio 45 (Suppl 3): S287-S296.

Bank, A., C. Frohlich, and A. Schneiker. 2017. The Political Dynamics of Human Mobility: Migration out of, as and into Violence. Global Policy 8: 12-18.

Bunce, A., and J. Ford. 2015. How Is Adaptation, Resilience, and Vulnerability Research Engaging with Gender? Environmental Research Letters 10: 1-11.

Camfield, L. 2011. 'A Girl Never Finishes Her Journey': Mixing Methods to Understand Female Experiences of Education in Contemporary Ethiopia. Research Papers in Education 26 (4): 393-412.

Campbell, E.K. 2010. The Role of Remittances in Botswana: Does Internal Migration Really Reward Sending Families? Population, Space and Place 16 (2): 151-164.

Chuta, N., and G. Crivello. 2013. Towards a 'Bright Future': Young People Overcoming Poverty and Risk in Two Ethiopian Communities.

Das, D., R.F. Grais, E.A. Okiro, K. Stepniewska, R. Mansoor, S. van der Kam, D.J. Terlouw, J. Tarning, K.I. Barnes, and P.J. Guerin. 2018. Complex Interactions between Malaria and Malnutrition: a Systematic Literature Review. BMC Medicine 16: 186-200. 
Devereux, S., and I. Scoones, I. 2006. The Crisis of Pastoralism? A Response to Stephen Sandford. Future Agricultures Consortium Debate. Brighton: Institute of Development Studies. http://www. future-agricultures.org/pdf\%20files/The_crisis_of_pastoralism.pdf.

Di Nunzio, M. 2015. What Is the Alternative? Youth, Entrepreneurship and the Developmental State in Urban Ethiopia. Development and Change 46 (5): 1179-1200.

Djoudi, H., B. Locatelli, C. Vaast, K. Asher, M. Brockhaus, and S. Basnett. 2016. Beyond Dichotomies: Gender and Intersecting Inequalities in Climate Change Studies. Ambio 45 (Suppl. 3): S248-S262.

Dorward, Andrew, S. Anderson, Y. Nava, J. Pattison, R. Paz, J. Rushton, and E. Sanchez Vera. 2009. Hanging in, Stepping up and Stepping out: Livelihood Aspirations and Strategies of the Poor Development in Practice. Development in Practice 19 (2): 240-247.

Guadu, T., and M. Abebaw. 2016. Challenges, Opportunities and Prospects of Dairy Farming in Ethiopia: A Review. World Journal of Dairy \& Food Sciences 11 (1): 01-09.

Kabeer, N. 2008. Gender Mainstreaming in Social Protection for the Informal Economy. London: Commonwealth Secretariat.

Little, P., K. Smith, B. Cellarius, D. Coppock, and C. Barrett. 2001. Avoiding Disaster: Diversification and Risk Management among East African Herders. Development and Change 32: 401-433.

Perez, C., E.M. Jones, P. Kristjanson, L. Cramer, P.K. Thornton, W. Förch, and C. Barahona. 2015. How Resilient Are Farming Households and Communities to a Changing Climate in Africa? A GenderBased Perspective. Global Environmental Change 34: 95-107.

Rao, N. 2019. From Abandonment to Autonomy: Gendered Strategies for Coping with Climate Change, Isiolo County, Kenya. Geoforum 102: 27-37.

Rao, N., E.T. Lawson, W.N. Raditloaneng, D. Solomon, and M.N. Angula. 2019. Gendered Vulnerabilities to Climate Change: Insights from the Semi-arid Regions of Africa and Asia. Climate and Development 11 (1): 14-26.

Sandford, S. 2006. Too Many People, Too Few Livestock: The Crisis Affecting Pastoralists in the Greater Horn of Africa. Future Agricultures Consortium Debate. Brighton: Institute of Development Studies. https://www.future-agricultures.org/wp-content/uploads/pdf-archive/Sandford_thesis.pdf. Accessed 10 Nov 2019.

Tafere, Y. 2014. Education Aspirations and Barriers to Achievement for Young People in Ethiopia. Young Lives. Young Lives Working Paper 120.

Tschakert, P., and M. Machado. 2012. Gender Justice and Rights in Climate Change Adaptation: Opportunities and Pitfalls. Ethics and Social Welfare 6: 275-289.

UNESCO (2017) Concept Note for the 2019 Global Education Monitoring Report on Education and Migration. https://en.unesco.org/gem-report/sites/gem-report/files/Concept\%20Note\%205\%20Apr il\%20Final.pdf. Accessed 5 July 2019.

Whitehead, A. 1998. Gender, Poverty and Intra-household Relations in Sub-Saharan Africa Small Holder Households: Some Lessons from Two Case Examples. Background Paper for 1998 Status of Poverty in Africa Report.

Publisher's Note Springer Nature remains neutral with regard to jurisdictional claims in published maps and institutional affiliations. 